\title{
Vacuum-Sealing as a Treatment Option for Severe Anthracycline Extravasation in a Breast Cancer Patient
}

\author{
Kerstin Rhiem ${ }^{a} \quad$ André T. Nemat ${ }^{b} \quad$ Rita K. Schmutzler ${ }^{a} \quad$ Matthias Krick $^{c} \quad$ Peter Mallmann $^{a}$ \\ Mathias Warm ${ }^{\mathrm{a}}$ \\ a Department of Obstetrics and Gynecology, University of Cologne School of Medicine \\ ${ }^{b}$ Department of Cardiothoracic Surgery, University of Cologne School of Medicine \\ ${ }^{c}$ Moers, Germany
}

\section{Key Words}

Extravasation - Vacuum-sealing therapy .

Venous catheter port - Breast cancer - Chemotherapy

\section{Summary}

Background: Compared to peripheral venous access, central lines greatly reduce the incidence of cytotoxic extravasation. Although implantable vascular systems are widely used in oncology, extended extravasation lesions in cancer patients remain complicated. Patient and Method: A 67-year-old female breast cancer patient suffered from an extended lesion of a catheter port extravasation. A vacuum-sealing therapy was initiated to accelerate the healing of the anthracycline-induced wound. Result: The vacuum-sealing technique allowed a fast and successful treatment of the extravasation lesion. Conclusion: Due to the myelosuppressive chemotherapy regimen, the risk of wound infections and prolonged healing processes is increased in cancer patients. Moreover, disruption or cancellation of anticancer therapies worsens the patients' prognosis. To attenuate these complications the vacuum-sealing technique should be considered in wound management concepts.

\section{Introduction}

Central venous catheter ports are well established in clinical oncology to assure a reliable venous access for patients receiving chemotherapy and repetitive blood sampling. However, extravasation is a complication with an estimated frequency of $0.01-0.26 \%$ of all patients $[1,2]$. Extravasation lesions of anthracyclines, an integral cytotoxic group of drugs in chemotherapeutic regimens against breast cancer, are mostly devas-

\author{
Schlüsselwörter \\ Paravasat - Vakuumverband - Portkathetersystem . \\ Mammakarzinom · Chemotherapie
}

\section{Zusammenfassung}

Hintergrund: Durch zentralvenöse Gefäßzugänge kann das Risiko von Paravasaten während einer Chemotherapie deutlich reduziert werden. Doch trotz der weitverbreiteten Anwendung implantierbarer Portsysteme in der Onkologie stellen Paravasate für Krebspatienten nach wie vor eine schwerwiegende Komplikation dar. Patientin und Methode: Eine 67-jährige Brustkrebspatientin erlitt ein ausgedehntes Anthrazyklin-Paravasat. Ein Vakuumverband wurde angelegt, um den Wundheilungsprozess zu beschleunigen. Ergebnis: Durch diese Behandlungsmethode kam es zu einer zügigen Abheilung des Defekts. Schlussfolgerungen: Bei Patienten unter Chemotherapie ist das Risiko für Wundheilungsstörungen und Wundinfektionen erhöht. Solche Komplikationen führen nicht selten zu einer Unterbrechung oder gar Beendigung der Chemotherapie und verschlechtern die Prognose der Patienten. Daher sollten Vakuumverbände in modernen Wundbehandlungskonzepten von Paravasaten berücksichtigt werden.

tating. The acute local reaction is characterized by pain, edema and erythema. The chronic process after weeks or even months is probably boosted by drug persistence in the tissue and consists of ulceration and necrosis [3].

\section{Case Report}

A 67-year-old female breast cancer patient was admitted to our department with an extended, chronic ulceration of the left breast and thoracic

\section{KARGER}

Fax +497614520714

Information@Karger.de

www.karger.com (c) 2008 S. Karger GmbH, Freiburg

Accessible online at:

www.karger.com/brc
Dr. med. Kerstin Rhiem

Klinikum der Universität zu Köln

Klinik und Poliklinik für Frauenheilkunde und Geburtshilfe

Kerpener Str. 34, 50931 Köln, Germany

Tel. +49 478 86509, Fax -510

kerstin.rhiem@uk-koeln.de 
Fig. 1. Extended tissue damage after anthracycline extravasation and surgical debridement.

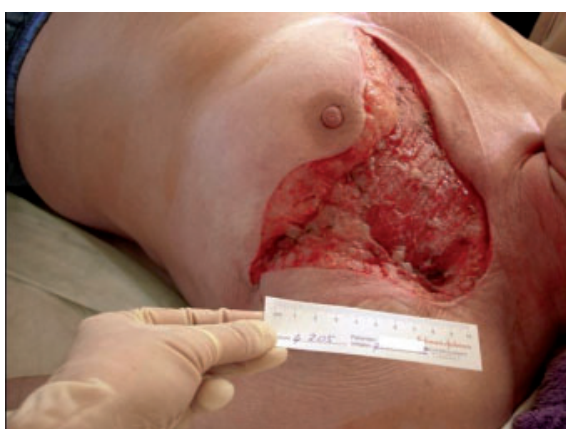

wall due to an epirubicin extravasate 18 weeks ago. It derived from an inappropriate needle insertion into a central venous catheter port during the second course of an adjuvant anthracycline-based chemotherapy. The first course was administered without any complication 3 weeks after a breast-conserving operation of a stage IIA breast cancer (pT1c, pN1biii, $\mathrm{M} 0$, grading 2, estrogen receptor positive, progesterone receptor positive, Her2/neu negative). The first intervention immediately after extravasation consisted of local application of dimethyl sulfoxide (DMSO, 99\%) and topical cooling. After 2 weeks, the extravasation area was marked by a persistent erythema, induration, and pain. Subsequently, the tissue damage proceeded and infections aggravated the process despite diverse local treatment efforts.

On physical examination, a purulent exulceration measuring $12 \times 15 \mathrm{~cm}$ covered the left thoracic wall. The extended wound accounted for a permanent analgesic therapy. In the computed tomography scan, the thoracic wall revealed a fibrosis surrounding the central venous catheter port, but no extension to any deeper structure was discovered. Moreover, there was no other abnormal result of the clinical examination; full blood count, sedimentation rate and biochemistry were normal. Contrary to medical advice, the patient continued to smoke approximately 20 cigarettes per day. She received an aromatase inhibitor while, due to the extended wound, neither completion of the adjuvant chemotherapy nor obligatory irradiation of the right breast could be performed.

She underwent an extensive surgical debridement of the ulceration up to the fascia of the pectoralis muscle (fig. 1). The skin surrounding the wound was widely excised and the central venous catheter port, revealing no leakage, was removed. Histopathological investigation of the tissue exhibited a chronic infection without any malignancy. After the operation, a vacuum-sealing therapy with a polyurethane foam using nonadhering gauze and negative pressure ranging from 80 to $120 \mathrm{~mm} \mathrm{Hg}$ was initiated. Under the decontaminating conditions of the vacuum-sealing technique, healing proceeded without any infection (fig. 2a, b). At 31 days after starting the therapy, the sufficiently perfused wound had decreased significantly and the patient could be referred to the outpatient clinic (fig. 2c, d). At the 3-month follow-up examination, the patient presented with a complete wound closure (fig. 2e, f). A breast reconstruction combined with a scar correction is planned.

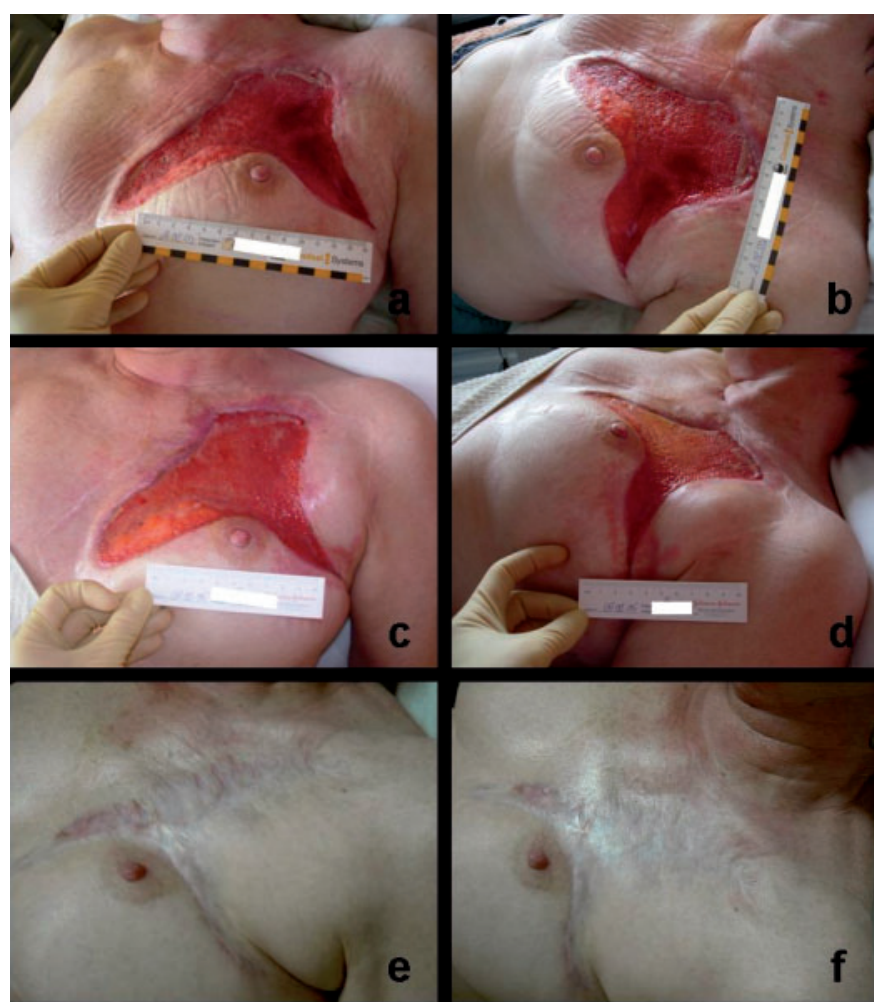

Fig. 2. Wound healing process after 20 days $(\mathbf{a}, \mathbf{b})$ and 31 days (b, c of vacuum-sealing therapy and at the 3-month follow-up examination $(\mathbf{e}, \mathbf{f})$.

\section{Discussion}

Therapeutic strategies of anthracycline extravasation are still controversial since proven standards hitherto do not exist. Non-surgical treatments, e.g. local cooling and topical application of DMSO often take place in the initial phase of extravasation. Moreover, 4 prospective multicenter studies show the topoisomerase II inhibitor, dexrazoxane, as an effective and well-tolerated acute treatment with only 1 out of 54 or 57 patients requiring surgical resection $[4,5]$. While surgical excision, frequently followed by mesh-graft transplantation, is necessary in advanced stages of ulceration, the vacuum-sealing technique should be considered in extravasation management to shorten the healing process and to increase the patient's quality of life [6].

\section{References}

1 Langstein HN, Duman H, Seelig D, et al.: Retrospective study of the management of chemotherapeutic extravasation injury. Ann Plast Surg 2002;49: 369-374.

2 Biffi R, Pozzi S, Agazzi A, Pace U, Floridi A, Cenciarelli S, Peveri V, Cocquio A, Andreoni B, Martinelli G: Use of totally implantable central venous access ports for high-dose chemotherapy and peripheral blood stem cell transplantation: results of a monocentre series of 376 patients. Ann Oncol 2004; 15:296-300.
3 Sonneveld P, Wassenaar JA, Nooter K: Long persistence of doxorubicin in human skin after extravasation. Cancer Treat Rep 1984;68:895-896.

4 Mouridsen HT, Langer SW, Buter J, Eidtmann H, Rosti G, de Wit M, Knoblauch P, Dahlstrom K, Jensen PB, Giaccone G: Treatment of anthracycline extravasation with Savene (dexrazoxane): results from two prospective clinical multicentre studies. Ann Oncol 2007:18:546-550.
5 Kane RC, McGuinn WD Jr, Dagher R, Justice R, Pazdur R: Dexrazoxane (Totect): FDA review and approval for the treatment of accidental extravasation following intravenous anthracycline chemotherapy. Oncologist 2008;13:445-450.

6 Ubbink DT, Westerbos SJ, Evans D, Land L, Vermeulen H: Topical negative pressure for treating chronic wounds. Cochrane Database Syst Rev 2008:3:CD001898. 